\title{
QUALITY OF THE LIVING ENVIRONMENT IN THE NEIGHBORHOOD OF MURGLE - SCANDINAVIAN URBANISM IN LJUBLJANA
}

Dejan Rebernik, PhD.

Department of Geography, Faculty of Arts, University of Ljubljana

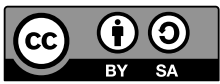

Aškerčeva 2, SI-I000 Ljubljana

e-mail: dejan.rebernik@ff.uni-lj.si

Original scientific article

COBISS 1.01

DOI: $10.4312 /$ dela.46.5.123-141

\begin{abstract}
The main characteristic that distinguishes the Murgle housing estate from other residential areas in Ljubljana is its specific and unique urban design inspired by Scandinavian urbanism. The main goal of the paper is to present an evaluation of residents' satisfaction with the quality of the living environment, 50 years after its construction commenced. We also analyzed gradual spatial, urbanistic and social transformations of the neighborhood over time. On the basis of the survey carried on among the residents we established that the neighborhood, despite many unregulated interventions not in accordance with its urban design, maintained a high quality of living environment.
\end{abstract}

Key words: Ljubljana, Murgle, quality of the living environment, urbanism, France Ivanšek

\section{KAKOVOST BIVALNEGA OKOLJAV SOSESKI MURGLE - SKANDINAVSKI URBANIZEMV LJUBLJANI}

\section{Izvleček}

Osnovna značilnost, po kateri se soseska Murgle razlikuje od preostalih stanovanjskih območij v Ljubljani, je njena edinstvena urbanistična zasnova, ki izhaja iz tradicije skandinavskega urbanizma. Glavni namen prispevka je ocena zadovoljstva stanovalcev s kakovostjo bivalnega okolja 50 let po nastanku soseske. Poleg tega smo preučili postopno prostorsko, urbanistično in socialno preobrazbo soseske skozi čas. Na osnovi anketiranja prebivalstva smo ugotovili, da je soseska kljub številnim nedovoljenim posegom, ki niso skladni z osnovnim urbanističnim konceptom, zadržala visoko kakovost bivalnega okolja.

Ključne besede: Ljubljana, Murgle, kakovost bivalnega okolja, urbanizem, France Ivanšek 


\section{INTRODUCTION}

The Murgle neighborhood was constructed between the end of the 1960s and the middle of the 1980s during the most intensive period of public housing development in Ljubljana and Slovenia. The vast majority of public housing in this period was built in the form of high-rise housing estates. High-rise housing estates were considered as the most suitable form of residential developments from an economic, urbanistic and ideological point of view. Public construction of individual family houses was seen as not "appropriate" given the values of the socialist society. On the other hand, public opinion surveys (Toš, 2014) showed that the majority of Slovenes wanted to live in a single family house with a small garden, but close to services offered by urban centers. Architects France and Marta Ivanšek proposed constructing a completely different housing estate of low atrium houses. Due to its location on the Ljubljana Marshes (Ljubljansko Barje) the terrain had low carrying capacity and high-rise construction would be very expensive if not impossible, while the location close to the city center demanded a relatively high population density. With his urban layout, which was inspired by Scandinavian urbanism, France Ivanšek managed to obtain population density above 100 inhabitants per hectare (compared to around 30 to 50 with detached single family houses). The urban form and architecture of the estate were deliberately simple; the costs of construction were low. In the first phase of the construction, at the end of the 1960s, social housing in small and very basic atrium houses was offered. However, in the second phase, in the 1970s, higher quality construction and bigger houses, together with the neighborhood's very green and quiet environment close to the city center, attracted residents with higher socio-economic status. With further expansion, Murgle turned into a very popular and "elite" neighborhood.

The main characteristic that distinguishes Murgle from other residential areas in Ljubljana is its specific and unique urban design inspired by Scandinavian urbanism that will be presented in more detail in a separate chapter. For that reason, the Murgle neighborhood is protected as an area of architectural and urban heritage and all interventions are strictly regulated by a building plan. Our research hypothesis was that this kind of urban design results in a high-quality living environment. The main goal of the paper is thus to present an evaluation of the satisfaction with the quality of the living environment and more specifically with the neighborhood's urban design expressed by its residents, 50 years after its construction began. We also analyze gradual spatial, urbanistic and social transformation of the neighborhood over time. Despite strict architectural and urban planning regulations, spatial development in the form of different renovations, enlargement of houses and other kinds of interventions has been more or less uncontrolled and for that reason chaotic. In this way, the urban heritage of the neighborhood is being degraded. In contrast, we wanted to establish whether the neighborhood, despite its many unregulated interventions not in accordance with its urbanistic concept, maintained a high quality of the living environment. In addition, we wanted to find out what the position of Murgle is in the modern social geography of Ljubljana and what kind of further development and transformation processes we might expect in the future. 
The research was based on analysis and interpretation of statistical data (Population Census 1991 and 2011), fieldwork analysis of the spatial and urbanistic transformation of the neighborhood and, to the greatest extent, on surveys conducted among residents of the neighborhood.

\section{THEORETICAL AND METHODOLOGICAL FRAMEWORK OF THE RESEARCH}

The study of the quality of the living environment is an important research topic in geography. Pacione (2003) considers that studying the relationship between society and its environment is one of the basic research questions in social geography. The research on the quality of living environments in cities is also an important element of modern urbanism (Leitmann, 1999). It can contribute to better and more efficient urban planning and urban policies. Very popular are methods of measuring and comparing the quality of living environments in cities, the results of these approaches are different quality of living rankings for world cities, for example Mercer Quality of Living Ranking. Research on the quality of living environments in Slovene towns has been carried out by geographers (Špes, 1998; Drozg, 1994; Rebernik, 2002; Krevs, 1998; 2002), and also by sociologists and economists (Mlinar, 1983; Uršič, Kos, 2004; Mandič, Cirman, 2006).

One of more general definitions of the living environment is "a space in which an individual fulfills its basic needs and social functions" (Tiran, 2015). Living environments have different spatial dimensions and most authors distinguish three levels: dwelling, neighborhood, city (Pacione, 2003). Our research is limited to the level of dwelling and neighborhood. In this research, based on different theoretical and methodological approaches, we defined the living environment as the characteristics of a dwelling and its surroundings which are important for the fulfillment of basic human needs and functions. The quality of the living environment is an evaluation of living conditions and circumstances. There are two main approaches to evaluate the quality of living environments: objective and subjective. An objective approach is based on a quantitative measurement of the quality of a living environment. Its main advantage is objective evaluation of different characteristics of living environments, its weakness is the impossibility of measuring all elements of living environments and available data is often of poor quality (Tiran, 2015). In the subjective approach, we measure the quality of a living environment on the basis of residents' subjective evaluation of the studied area. The subjective approach derives from behaviorism (Tiran, 2015) and is based on surveying local population. In this way, we can evaluate a much wider range of quality of living environment elements.

The study of the quality of the living environment can include different dimensions: quality of housing, quality of services, quality of environment, accessibility, aesthetic evaluation, security, quality of social interactions and similar. In our research, we focused on selected dimensions of the quality of the living environment: quality of housing, quality of urban layout, security and aesthetic evaluation. The main aim of the research was to evaluate the level of satisfaction of residents with the quality of the living environment 
in their neighborhood based on the characteristics of its urban design. In other words, we wanted to establish if residents are satisfied with the living conditions that result from the unique and specific architectural and urban design of their neighborhood.

The main empirical method used in our research was surveying of local population. Apart from that, we conducted basic statistical analysis and an expert evaluation of the spatial transformation in our study area. In the statistical analysis, we compared selected data on socio-economic and demographic characteristics of the population in the Murgle neighborhood with those for the Municipality of Ljubljana in its entirety. In this manner, we evaluated the position of the neighborhood of Murgle in the context of the social geography of Ljubljana. We also compared data from the 1991 and 2012 Population Censuses to delineate the main processes of social transformation. One of the goals of our study was to evaluate spatial transformation of the neighborhood from an architectural and urbanistic point of view. In the expert evaluation, we tried to identify the most widespread and common interventions that had occurred not in accordance with urban planning regulations.

The survey was carried out in January 2016 by geography students from the Department of Geography, University of Ljubljana. 380 surveys were completed. In the entire neighborhood, there are around 750 houses, so approximately $50 \%$ of households were interviewed. We applied a simple random sample where each individual was chosen randomly and entirely by chance, such that each individual had the same probability of being chosen at any stage during the sampling process. Our sample, which included $50 \%$ of the neighborhood, is thus highly representative. A detailed analysis of the survey results is presented in chapter 5 .

\section{URBANISM OF MURGLE NEIGHBORHOOD}

The Murgle neighborhood is an example of low density urban design. Its creator, architect France Ivanšek, was a great advocate of this type of urban layout; he stressed its advantages in his book "Single Family House: from single standing to low density layout" (Ivanšek, 1988). In all surveys about living preferences (Toš, 2014), the vast majority of the Slovene population expressed a preference for living in a single family house with a garden, though practically all public housing construction was in the form of apartments in smaller or larger condominiums. Ivanšek was trying to unify the advantages of both types of housing in a new type of housing development. On the one hand, he was very critical towards the widespread practice in Slovenia of building individual single family houses on large building plots (on average $500 \mathrm{~m}^{2}$ to $1000 \mathrm{~m}^{2}$ ) with the house usually located in the middle of the building plot. Houses were most often also too large for one family. This kind of housing is very demanding of space, energy and maintenance costs, and is therefore not suitable for urban areas. On the other hand, public housing in the form of large high-rise housing estates, whilst much more effective from the standpoint of population density, was not popular among its residents and offered relatively low quality of living environment. He proposed a new type of neighborhood, composed of low row or atrium houses, which in Slovenia were not very common in organized public housing developments. He was convinced that this kind of residential neighborhood would be very suitable for Slovene urban areas. It would 
be possible to obtain high enough population densities (up to 200 inhabitants per hectare) and a much better quality of living environment than in high-rise housing estates.

The main characteristics of urban layout and design of Murgle neighborhood are as follow:

- The urban layout is to the greatest extent possible in accordance with the environment of Ljubljansko Barje for example with local streets being located along natural rows of trees, which gave the neighborhood right from its construction the patina of being old. In addition, the streets are named after the variety of trees planted along them, which strengthens even more the atmosphere of a green neighborhood.

- The street system is designed according to Radburn, New Jersey (USA) with cul-de-sac streets and groups of around 35 houses lined by two streets and accessible only by pedestrian paths, but never more than 50 meters from the garage. This kind of street layout with separation of houses and garages provides a very calm environment almost free of car traffic. According to many experts and local inhabitants this is at the same time one of the main advantages as well as shortcomings of the urban design of the neighborhood.

Figure 1: Location of the Murgle neighborhood in Ljubljana.

Slika 1: Lokacija soseske Murgle v Ljubljani.

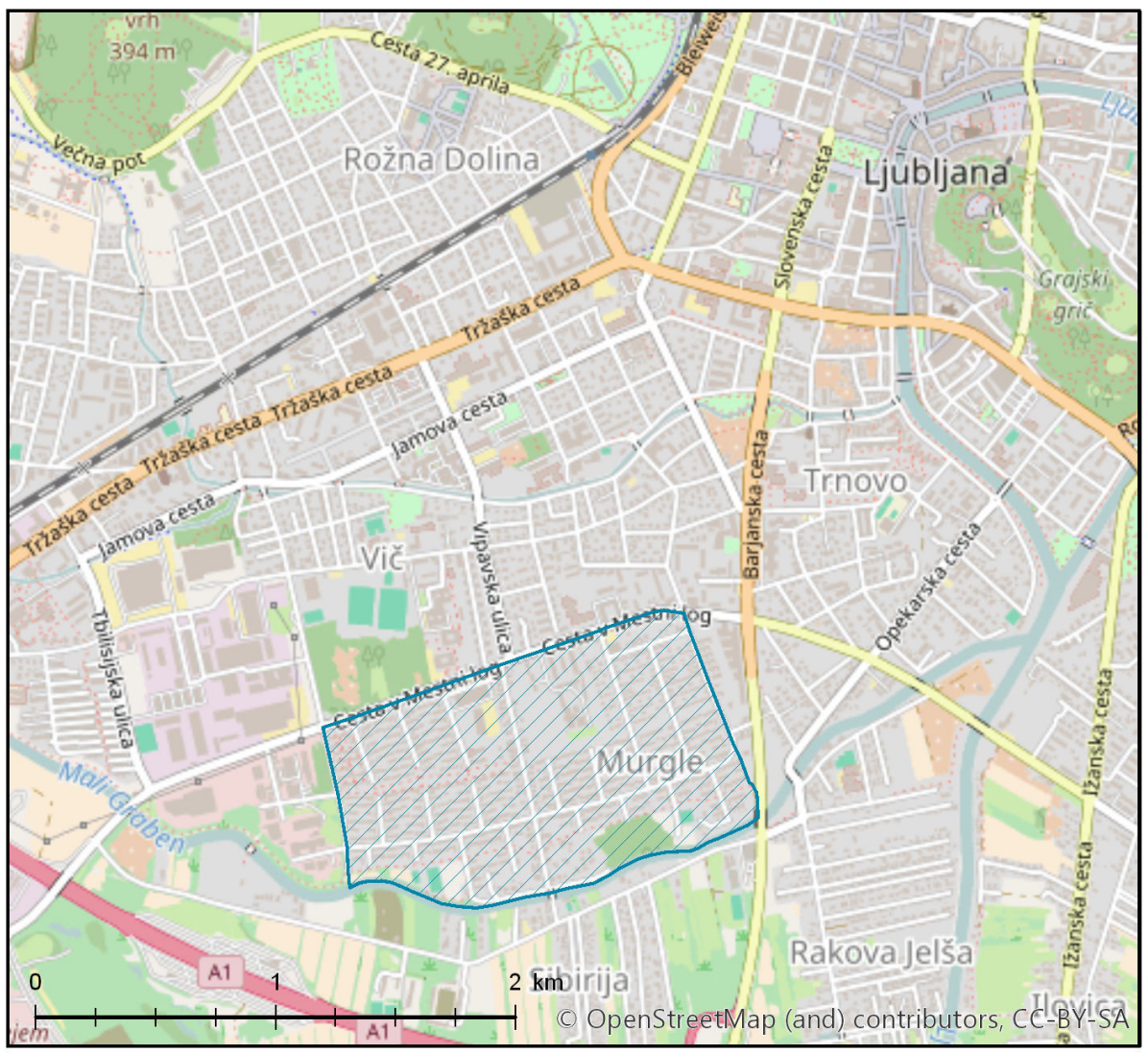


- The whole neighborhood has a uniform urban design with low atrium houses, closed internal gardens (with two meter high fences) and abundant public green spaces. This, on the one hand, enables a very intimate and calm living space including house and internal garden and, on the other hand, a complete fusion of private and public green areas.

- The houses are typified by unified architecture and a very rational internal plan, which is adapted to the needs of a typical four-member family. The interior of the house and the garden are visibly united by large windows. All this contributes to a very high quality living environment with relatively low construction and maintenance costs and efficient use of precious urban land.

- One of the main characteristics of the urban layout is the simplicity and neutrality of the architecture and its subordination to the surrounding environment. Public green spaces are abundant and a very important element of the neighborhood. The whole neighborhood is divided into three elements: the house; the internal atrium garden, which is an extension of the living room and offers complete intimacy; and public spaces with roads, paths and public green areas. The designers had the intention to achieve the complete interconnection of internal and external living space on the one hand, and of public and private living space on the other hand.

Figure 2: View of the Murgle housing estate in the year 1980.

Slika 2: Pogled na sosesko Murgle v letu 1980.

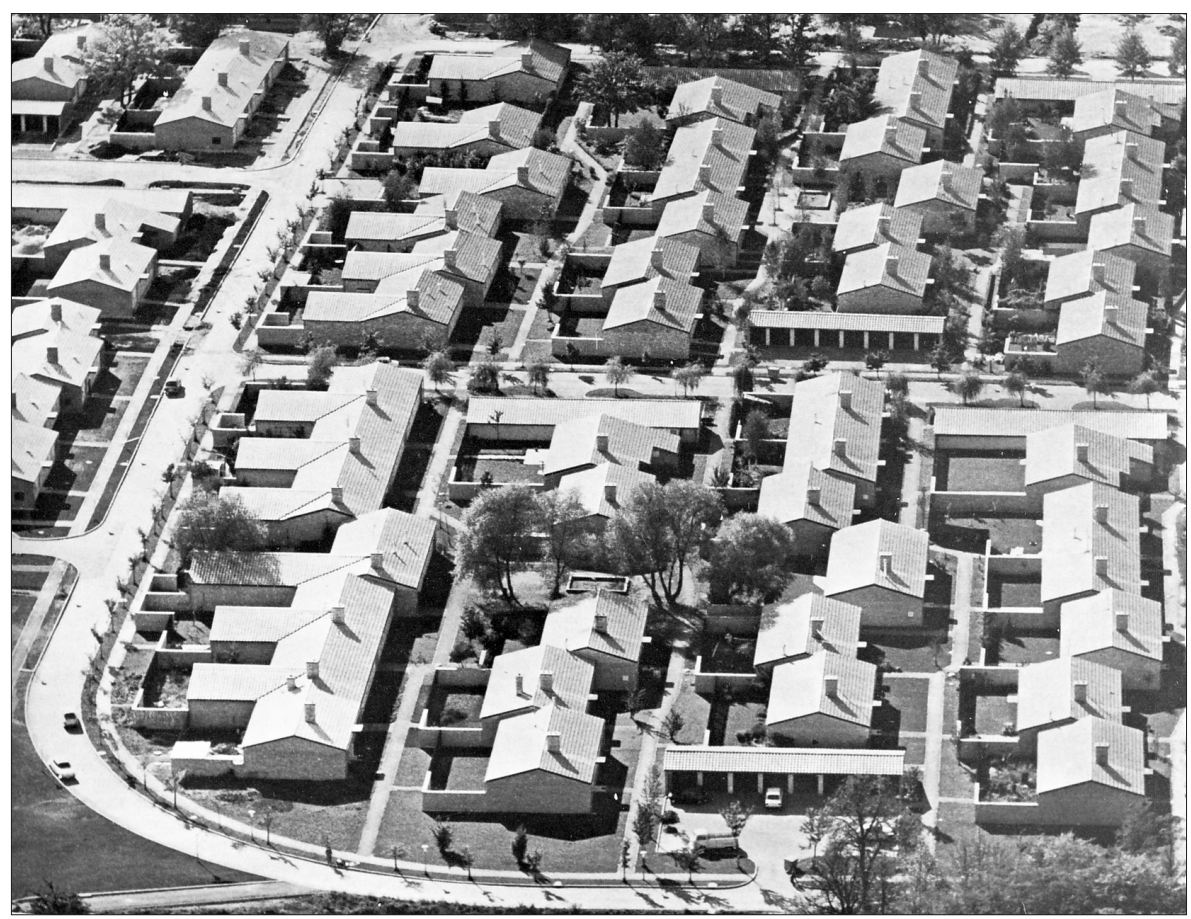

Source/Vir: France in Marta Ivanšek Foundation, 2016. 
As mentioned in the introduction, the Murgle housing estate is protected as an example of high-quality urban heritage. All renovations, extensions and other kinds of interventions are regulated by a building plan (Odlok o prostorskih ureditvenih pogojih za območje urejanja Murgle, 1999), in order to preserve the architectural and urban character of the neighborhood. The building plan describes in detail the allowed types and techniques of renovations, materials used, the dimensions of extensions and similar. The main goal of these regulations is protection of the architectural and urbanistic unity and quality of the housing estate as designed by its architects. In this way, the neighborhood can maintain its high-quality architecture and urbanism. In spite of detailed regulations, many illegal and unapproved spatial interventions took place in Murgle over the last decades. There are many examples of unregulated interventions that are diminishing the quality of architecture and urbanism, and at the same time the quality of the living environment in the housing estate. The most frequent types of unregulated interventions are:

- Unapproved extensions of private atrium gardens on private or even public land. In this way green areas outside private atrium gardens are devalued. Especially problematic is the shifting of the fence at the end of the atrium garden towards the pedestrian path.

- Adding an upper floor to a typical Murgle house. For a variety of reasons all houses in Murgle were designed as ground floor buildings.

- Inappropriate renovations that alter and devalue the architectural unity of the neighborhood.

Figure 3: An example of adding an upper floor to a house in Murgle (photo: D. Rebernik, 2016). Slika 3: Primer dograditve hiše s prvim nadstopjem (foto: D. Rebernik, 2016).

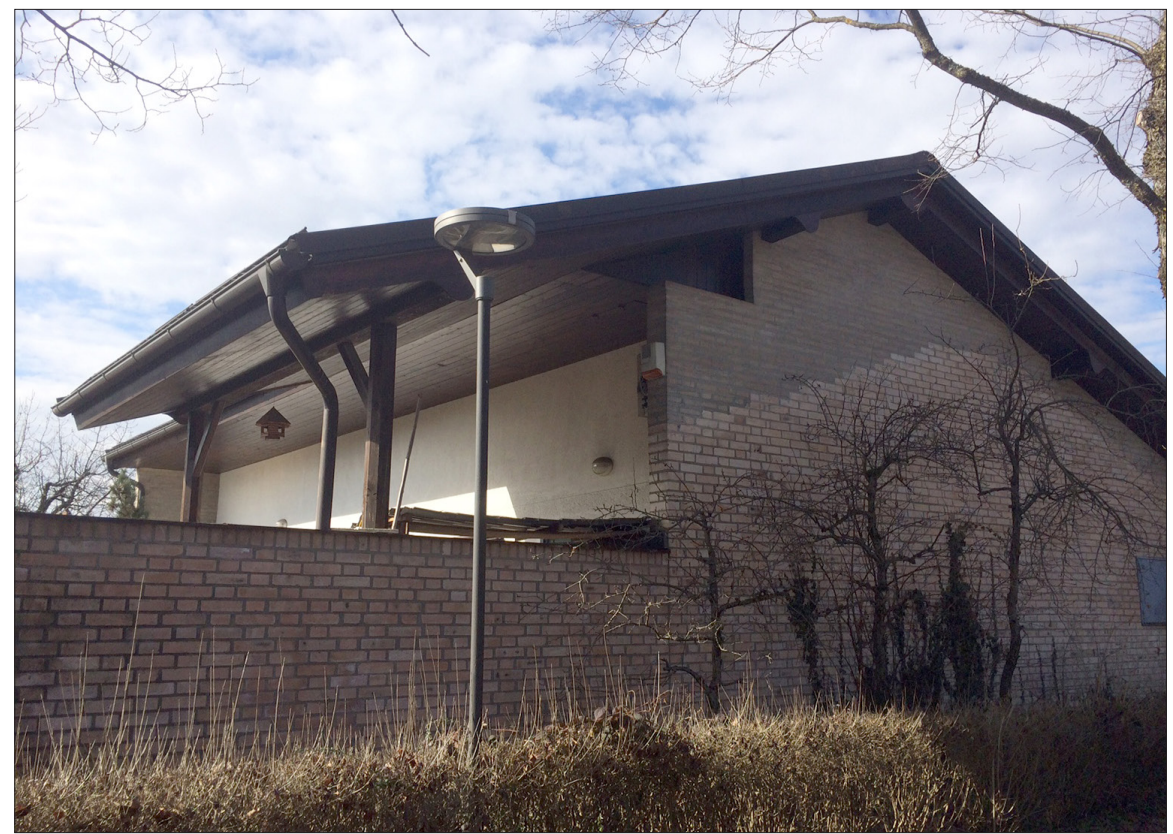


Figure 4: An example of extension of private atrium garden into public green space (photo: D. Rebernik, 2016).

Slika 4: Primer podaljšanja zasebnega atrijskega vrta na javne zelene površine (foto: D. Rebernik, 2016).

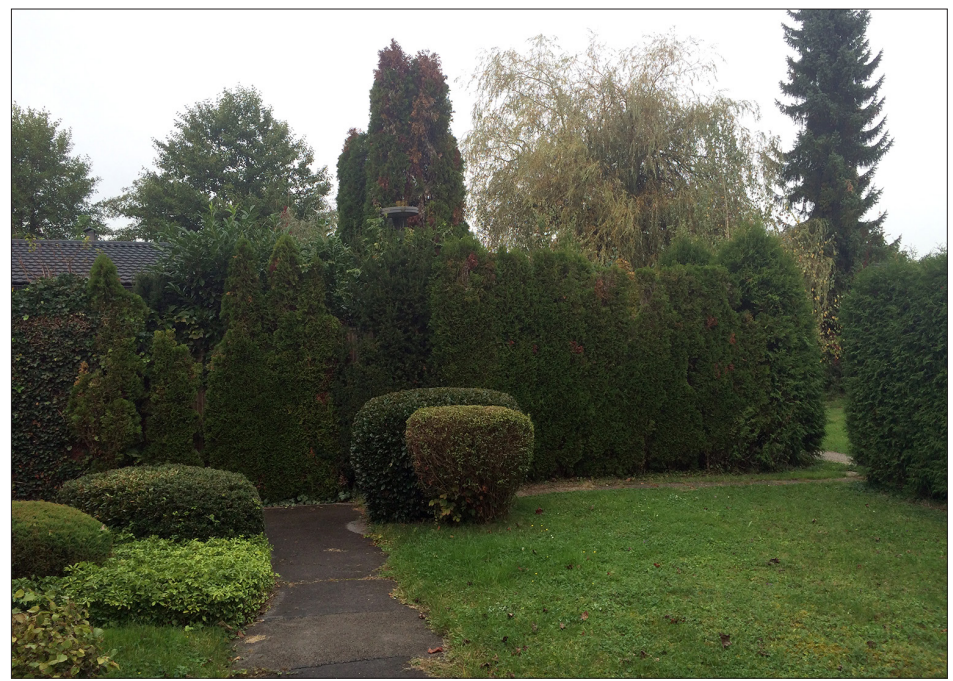

Figure 5: An example of moving the fence towards the pedestrian path (photo: D. Rebernik, 2016). Slika 5: Primer prestavitve ograje tik ob pešpot (foto: D. Rebernik, 2016).

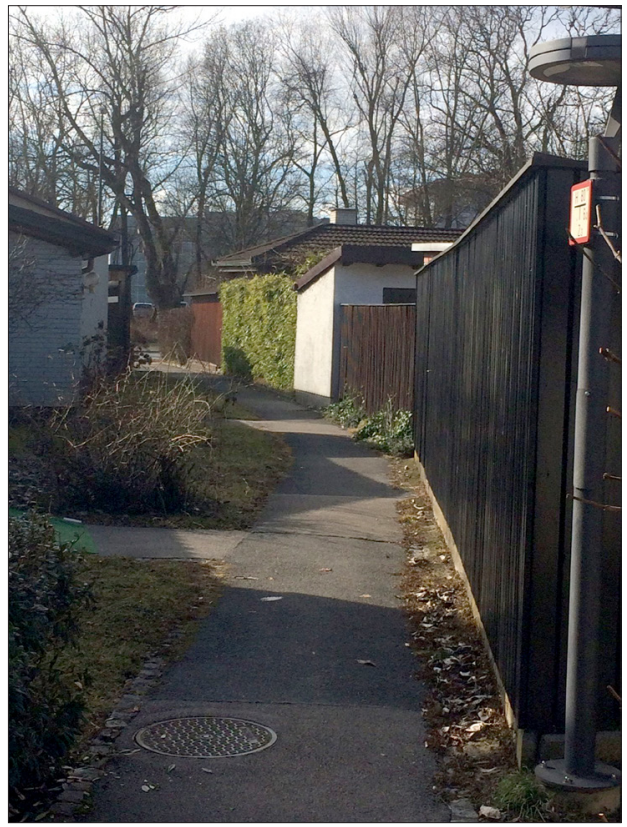




\section{SOCIO-ECONOMIC AND DEMOGRAPHIC CHARACTERISTICS}

At the beginning of construction at the end of the 1960s Murgle was conceived of as a housing estate for public social housing. The first prefabricated houses were deliberately small (around 60 to $80 \mathrm{~m}^{2}$ of living space) and the construction very economical. However, very soon, even in the second phase of construction in the beginning of the 1970s, the upper middle class recognized the advantages and attractiveness of this new neighborhood. Murgle thus became the most "elite" residential area in Ljubljana as early as the 1970s and 1980s. Intellectual, political and economic elites chose Murgle as a place of residence. In spite of declared social equality, social segregation occurred in the socialist socio-economic system as well. At the end of the socialist period, socio-economic polarization and distinct socio-economic areas were identifiable in Ljubljana (Rebernik, 1999). Statistical data from the 1991 Population Census thus confirms that out of all residential areas in Ljubljana the then population of the Murgle local community had the highest socio-economic status. At the time the local community of Murgle had the highest percentage of population with high education attainment (university degree), $42 \%$ compared to $18 \%$ for Ljubljana and $9 \%$ for Slovenia. The Population Census also gathered data on professional structure of the active population, revealing that out of all local communities Murgle was home to the second highest percentage of professionals (49\% compared to $27 \%$ for Ljubljana and $16 \%$ for Slovenia). Additionally, the population of Murgle was distinct with the highest income per capita. Income per capita was calculated based on tax base income, which every employed person has to declare and includes all income earned in a single year. Data is also available for 1993 and 1999. In 1993 average income per capita in the local community of Murgle exceeded the average for Ljubljana by $75 \%$ and in 1999 by 78\% (Rebernik, 1999; Krevs, 2002).

In spite of the emergence of many new high socio-economic areas and changes in the social geography of Ljubljana (Rebernik, 2013), the neighborhood of Murgle has retained the position of the residential area with the highest average socio-economic structure. From the 2011 Population Census it is evident that the local community of Murgle had retained the most favorable educational structure among all residential areas in Ljubljana. The proportion of the population with a university degree was $54.8 \%$ compared to the average value for the whole Urban Municipality of Ljubljana (UML) of 27.3\% (Figure 6 ). The data for income per capita was not available. The neighborhood was characterized by a very low unemployment rate as well (Figure 7).

The main characteristic of the demographic structure in Murgle is the ageing of its population. Similar to other residential areas in Ljubljana built in the 1970s and 1980s (Rebernik, 1999) the sharp predominance of older and older middle-aged population is typical. This is a consequence of a relatively homogeneous demographic structure of the population at the time of the construction of the new housing estate with a predominance of young families with small children and low mobility of residents. The process of gradual ageing of the population in a housing estate ensues. Similar processes were identified in other housing estates in Ljubljana (Rebernik, 1999). The proportion of the population aged over 55 years in Murgle is thus $48 \%$, compared to $31 \%$ in the UML. 
Figure 6: Educational structure of the population in Murgle and the UML in 2011. Slika 6: Izobrazbena sestava prebivalstva v soseski Murgle in v Mestni občini Ljubljana (UML) v letu 2011.

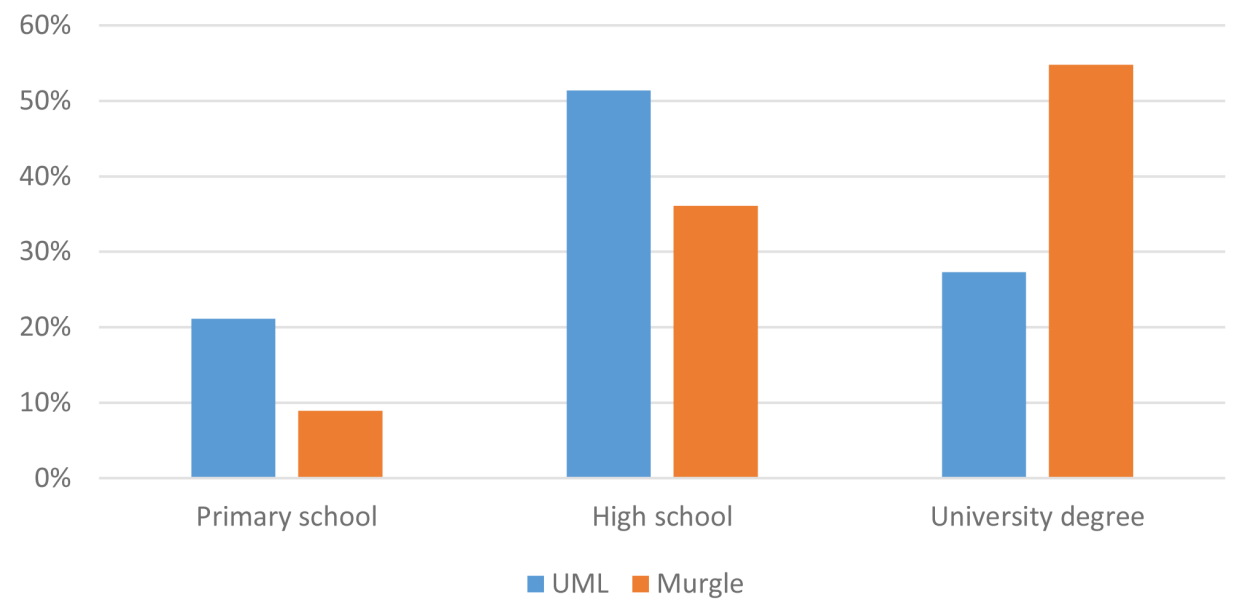

Source/Vir: Population Census, 2011.

Figure 7: Unemployment rate and percentage of pensioners in Murgle and the UML in 2011. Slika 7: Delež brezposelnih in delež upokojencev v soseski Murgle in v Mestni občini Ljubljana (UML) v letu 2011.

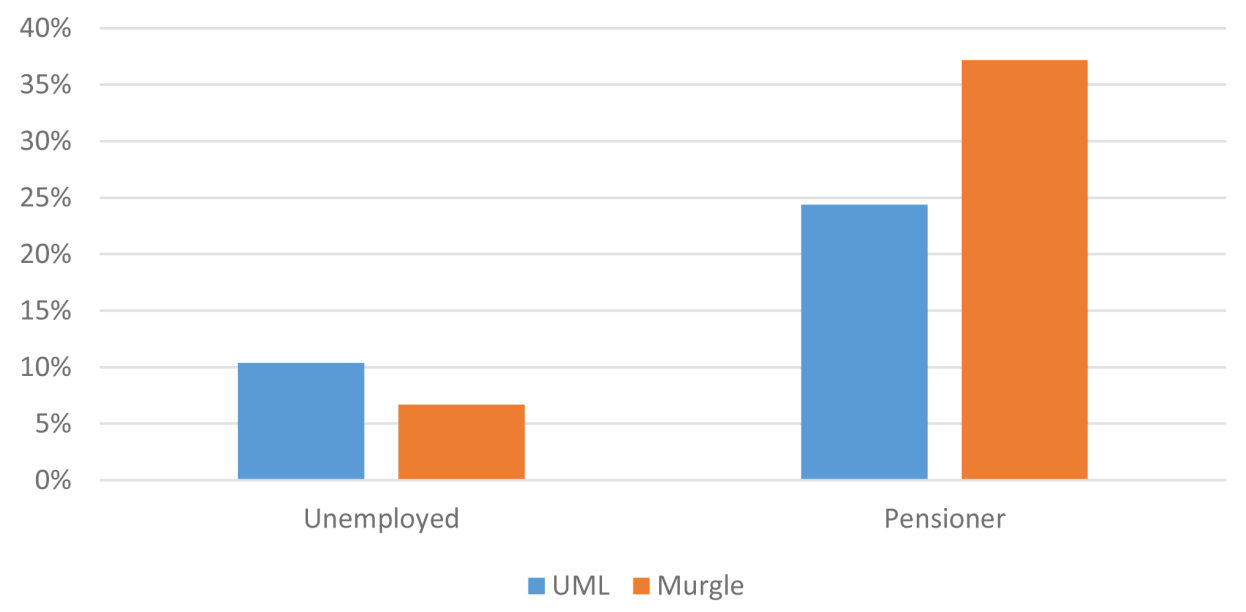

Source/Vir: Population Census, 2011. 
Figure 8: Age structure of the population in Murgle and the UML in 2011.

Slika 8: Starostna sestava prebivalstva v soseski Murgle in v Mestni občini Ljubljana (UML) v letu 2011.

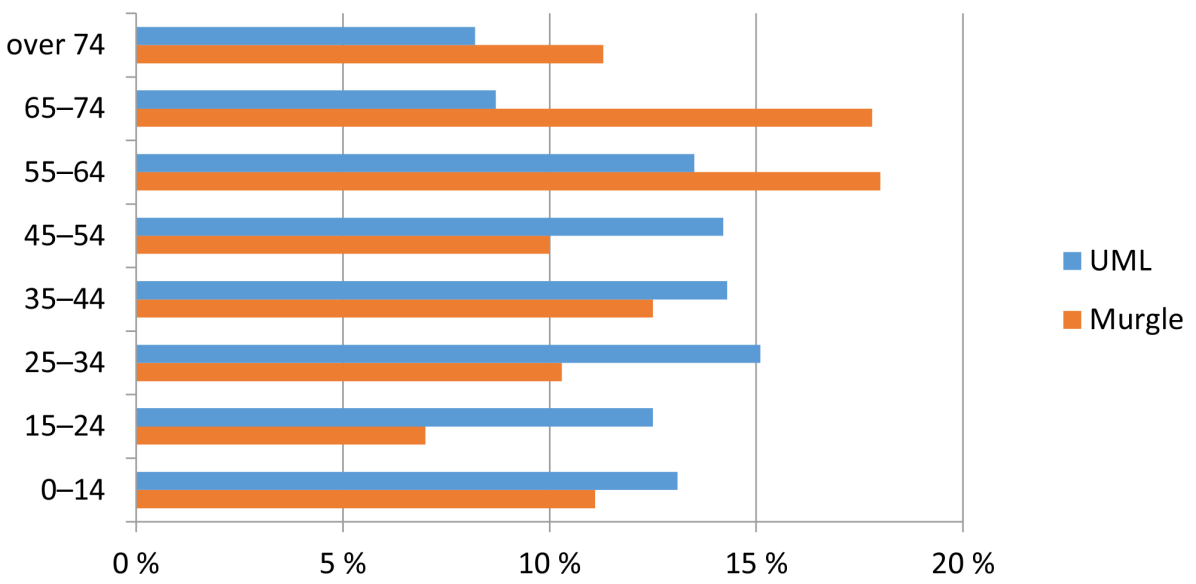

Source/Vir: Population Census, 2011.

\section{QUALITY OF THE LIVING ENVIRONMENT}

At the time of the construction of the first part of Murgle, namely at the end of the 1960 s, the media and public considered the neighborhood a great urbanistic failure. The first rows of small prefabricated houses with little greenery were even compared to the Dachau concentration camp. Gradually, due to improvements in building materials and techniques, but mostly due to its urbanistic concept that provided a green and high-quality living environment close to the city center, public opinion about the neighborhood changed. It soon became one of the most favorable locations to live in Ljubljana. The popularity of Murgle housing estate is to a great extent a reflection of its high-quality urbanism.

The survey conducted among residents of Murgle in January 2016 included 380 or $50 \%$ of all households in the neighborhood and is therefore highly representative. Exactly $50 \%$ of included households were composed of original residents and $40 \%$ of households composed of people who had moved to Murgle after 1990, which indicates relatively high mobility of population in the neighborhood. The main reasons for choosing the neighborhood were, in order of importance: good location close to the city center, single family house with a garden in a central location, good quality of the living environment, the status of an elite neighborhood, and good price.

Only $6 \%$ of households expressed an intention to move in the next five years, which is an indicator of a high level of satisfaction with the quality of the living environment in the neighborhood. General satisfaction with the quality of the living environment was evaluated with an average score of 4.1 out of 5 (Figure 9). $85 \%$ of respondents evaluated the general quality of the living environment as high or very high. The respondents were also 
very satisfied with the quality of their house, with the same average score of 4.1 out of 5 (Figure 10). This proves that the neighborhood remains very popular among its residents.

Figure 9: What is your general level of satisfaction with the quality of the living environment? Slika 9: Kakšno je vaše zadovoljstvo s kakovostjo bivalnega okolja?

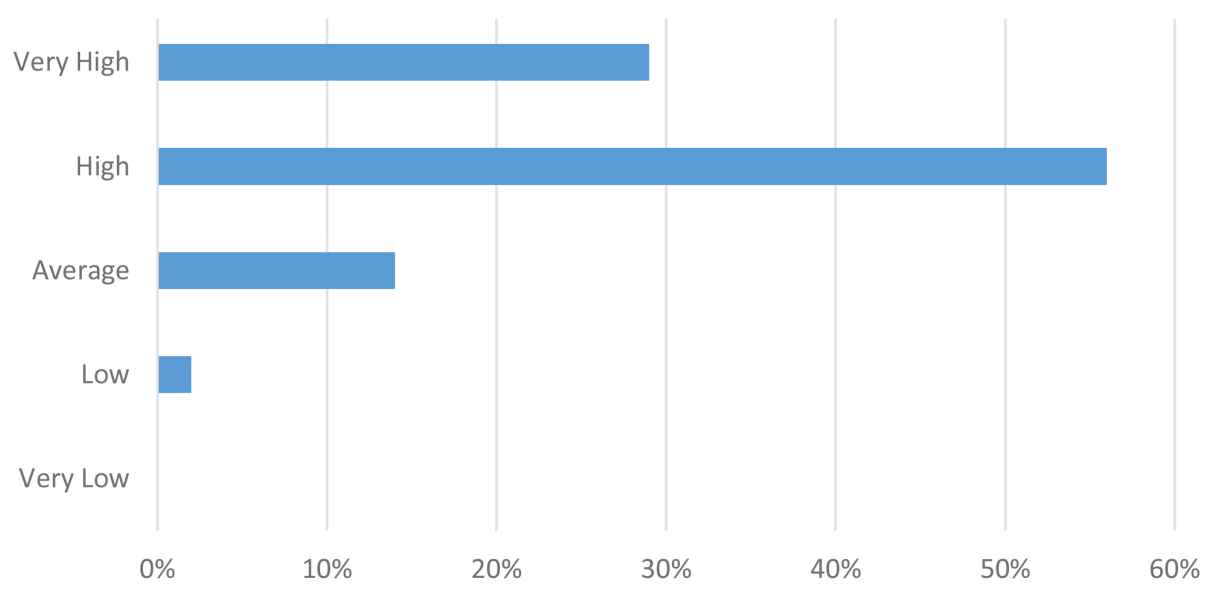

Note/Opomba: 1-very low, 2-low, 3-average, 4-high, 5-very high./1-zelo nizko, 2-nizko, 3-povprečno, 4-visoko, 5-zelo visoko.

Source/Vir: Own survey.

Figure 10: What is your level of satisfaction with the house?

Slika 10: Kakšno je vaše zadovoljstvo s stanovanjsko hišo?

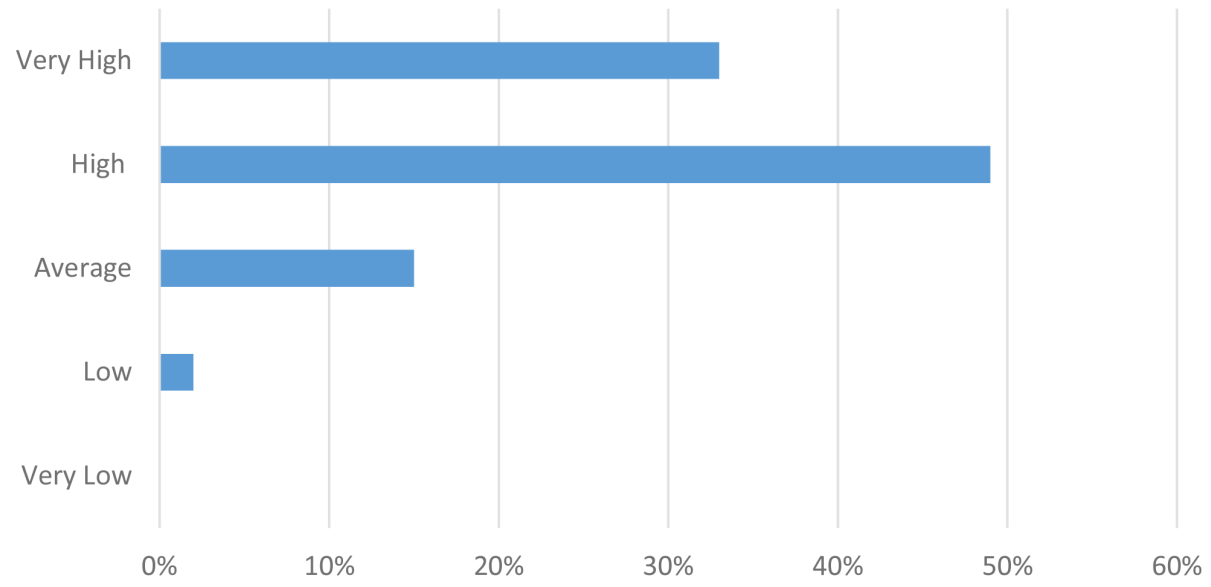

Note/Opomba: 1-very low, 2-low, 3-average, 4-high, 5-very high./1-zelo nizko, 2-nizko, 3-povprečno, 4-visoko, 5-zelo visoko.

Source/Vir: Own survey. 
Figure 11: How do you evaluate the importance of the following qualities/advantages of your neighborhood?

Slika 11: Kako ocenjujete pomembnost naslednjih prednosti vaše soseske?

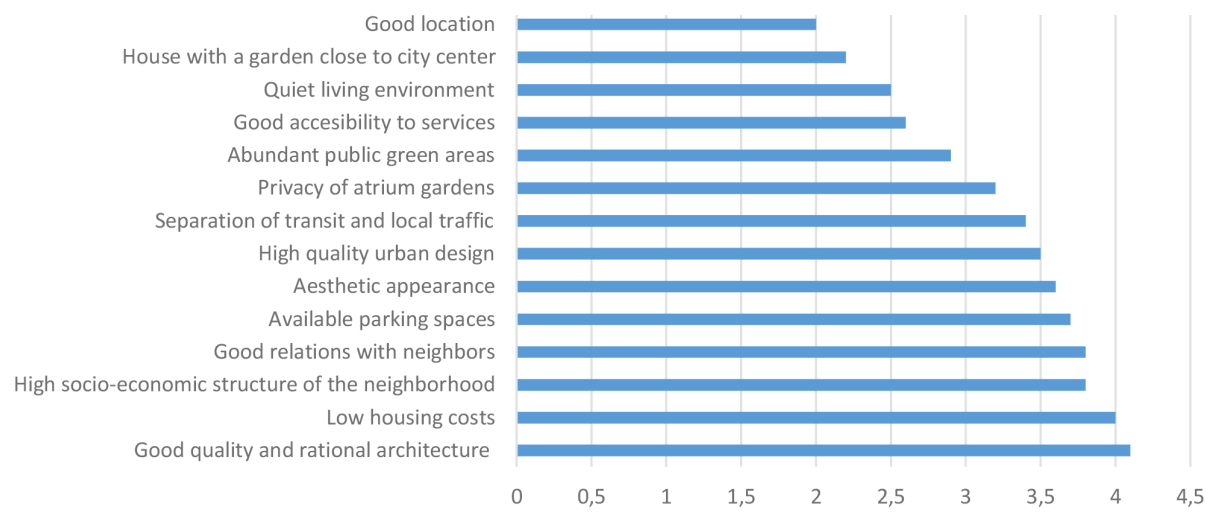

Note/Opomba: 1-very low, 2-low, 3-average, 4-high, 5-very high./1-zelo nizko, 2-nizko, 3-povprečno, 4-visoko, 5-zelo visoko.

Source/Vir: Own survey.

Figure 12: How do you evaluate the importance of the following weaknesses/shortcomings of your neighborhood?

Slika 12: Kako ocenjujete pomembnost naslednjih pomanjkljivosti vaše soseske?

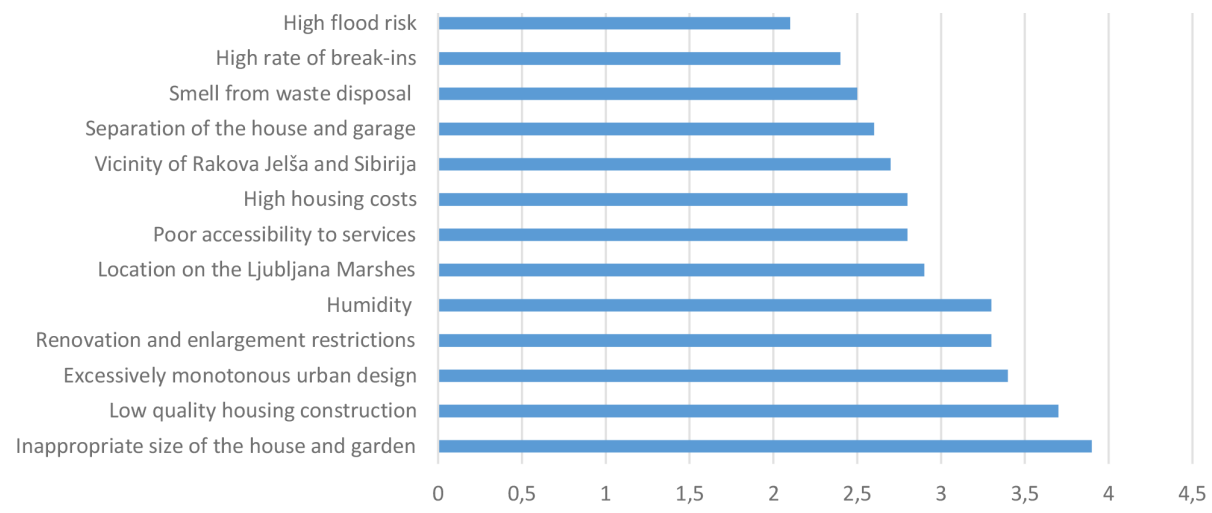

Note/Opomba: 1-very low, 2-low, 3-average, 4-high, 5-very high./1-zelo nizko, 2-nizko, 3-povprečno, 4-visoko, 5-zelo visoko.

Source/Vir: Own survey.

In the next group of questions, the respondents were asked to evaluate the importance of selected qualities/advantages and weaknesses/shortcomings of their neighborhood on a scale from 1 (very low) to 5 (very high). The proposed qualities/advantages and 
weaknesses/shortcomings were selected on the basis of the author's expert evaluation. In the proposed options, we were trying to include the main advantages and shortcomings of the neighborhood. Proposed qualities/advantages and weaknesses/shortcomings were chosen in a way to highlight the specific characteristics of the neighborhood, based on its architectural and urbanistic concept and design, location, social structure and similar. From the results of the survey it is evident that the residents evaluated key urbanistic characteristics as very important qualities of the neighborhood, including: good quality and rational architecture of houses, low housing costs, high quality of the urban design, aesthetic appearance, privacy of atrium gardens, abundant public green areas, low traffic - separation of transit and local traffic, and a quiet living environment. As main weaknesses/shortcomings the respondents highlighted the following characteristics: inappropriate size of the house and garden, low quality housing construction, excessively monotonous urban design, restrictions on renovations and enlargement of houses, separation of the house and garage, humidity, location on the Ljubljana Marshes, vicinity of neighborhoods Rakova Jelša and Sibirija, poor accessibility to services, smell from waste disposal, and a high rate of break-ins. It is evident that some weaknesses/shortcomings are connected with the urbanistic concept of the neighborhood (inappropriate size of the house and garden, low quality housing construction, excessively monotonous urban design, restrictions on renovations and enlargement of houses, and separation of the house and garage, high housing costs) and others to the location of the neighborhood (humidity, location on the Ljubljana Marshes, vicinity of neighborhoods Rakova Jelša and Sibirija, poor accessibility to services, smell from waste disposal). Approximately $50 \%$ of respondents were not satisfied with the size of the house. This was most often the case for households with old, single members for whom the house is too big and housing costs too high. Around one third of respondents considered the separation of the house and garage problematic. For some respondents, the unified urban design of the whole neighborhood is a good quality, but others consider it as "excessively monotonous". Opinions on renovations and enlargement of houses and gardens were divided: around one third of respondents oppose the practice of unregulated renovations and enlargements, while around a half do not consider this a problem and are unhappy with restrictions on renovations. Several weaknesses/shortcomings of the neighborhood are on account of its location: close to ethnic and low income neighborhoods of Rakova Jelša and Sibirija (around one third of respondents consider this as "a problem"; Rebernik, 2015); on the humid terrain of the Ljubljana Marshes; and close to the Barje regional waste disposal.

One of the main problems of the neighborhood is safety. The characteristics of the urban design (atrium gardens with high fences, low houses) and its socio-economic structure mean that break-ins occur very frequently. More than a third of respondents stated that their house had been broken into already. Over half of respondents have a security system (alarm, security camera) installed in the house. More than half of respondents also considered that a common security service financed by all residents is necessary. Initiatives to organize this common security system (night security guards etc.) had already been proposed but not yet realized. 
Figure 13: How do you evaluate the level of safety in the Murgle housing estate?

Slika 13: Kako ocenjujete stopnjo varnosti v soseski Murgle?

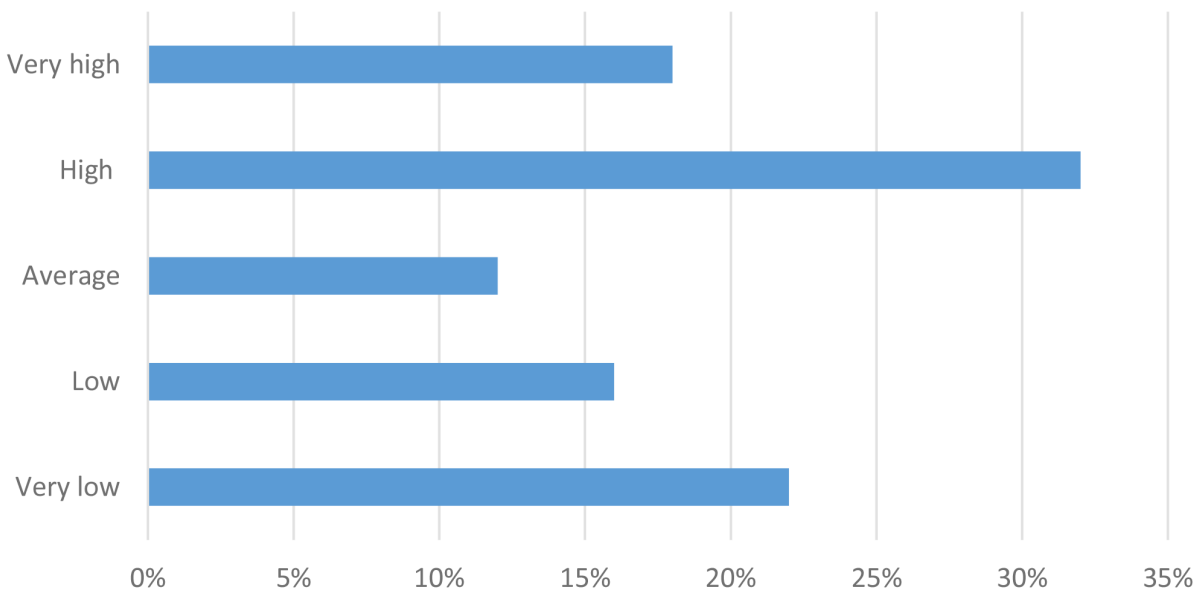

Note/Opomba: 1-very low, 2-low, 3-average, 4-high, 5-very high./1-zelo nizko, 2-nizko, 3-povprečno, 4-visoko, 5-zelo visoko.

Source/Vir: Own survey.

\section{CONCLUSION}

After a sharp decline in the 1990s, in the new millennium new housing construction increased in Ljubljana and other Slovene urban areas. The majority of new housing in Slovene urban and suburban areas is in the form of planned and organized construction of small housing estates by private investors (Rebernik, 2007). The quality of urbanism and resulting quality of the living environment of those new housing estates are very often low, featuring: too high population densities, limited green space, lack of parking spaces and traffic congestion, lack of privacy, etc. The urbanistic concept of Murgle on the other hand proved to be very successful and the neighborhood maintained a very high quality of living environment. The Murgle housing estate could thus be an example and inspiration for further housing development in Slovene urban and suburban areas.

The Murgle housing estate was developed between the end of the 1960s and the middle of the 1980 s, during the most intensive period of housing construction in Ljubljana and Slovenia. The vast majority of public housing construction in that period was in the form of high-rise housing estates. Murgle on the other hand offered an alternative solution in the form of a housing estate with a lower density urban layout inspired by Scandinavian urbanism. Its architects, France and Marta Ivanšek, wanted to create a housing estate of single family houses with a high-quality living environment, maintaining a relatively high population density with low construction costs. At the beginning of the construction, Murgle was envisaged as a housing estate for public social housing, but it soon became a high income residential area. 
Our research confirmed that Murgle, 50 years after the beginning of its construction, remains a very popular housing estate with a high quality living environment. From the results of the survey conducted, it is evident that the majority of residents are very satisfied with the quality of the living environment. The main advantages of the Murgle housing estate are: abundance of green areas, a very quiet living environment with separation of traffic and pedestrian areas, low housing costs, rational separation of public and private spaces with a high degree of privacy of houses and gardens, and a unified urban layout and architectural design. All these qualities are achieved whilst maintaining a very rational use of precious urban land: high population density, low construction and housing costs, and high proportion of public and private green areas.

France and Marta Ivanšek designed the Murgle housing estate at the end of the 1960s. The original urbanistic concept was respected throughout its construction. The majority of the neighborhood was completed in the middle of the 1980s; a small part at the southern edge is still not finished. The main aim of the architects was to create a housing estate with a high quality of living environment, whilst maintaining low construction costs and achieving a relatively high population density. The architecture and urbanism of the neighborhood are deliberately simple and rational. The sizes of houses and gardens are relatively small and adapted to the minimal needs of a four-member nuclear family. The architects wanted to offer an alternative to living in apartments in high-rise housing estates while maintaining similar construction costs. 50 years after the beginning of its construction, the standard of housing in Slovenia has improved and the housing market developed dramatically, offering much more varied and high quality housing. Despite the change in conditions and housing expectations, Murgle has maintained a position as one of the most desirable housing estates in Ljubljana, which is an additional proof of its remarkable urbanism.

\section{(Translated by James Cosier)}

\section{References}

Drozg, V., 1994. Kvaliteta bivalnega okolja v stanovanjskih območjih v Mariboru. In: Premzl, V. (ed.). Mednarodni simpozij Trajnostni urbani razvoj. Maribor, Tehniška fakulteta, $156 \mathrm{pp}$.

France in Marta Ivanšek Foundation [Ustanova France in Marta Ivanšek]. URL: http:// www.mao.si/Dogodek/Stanovanjsko-naselje-Murgle.aspx (11.11.2016).

Ivanšek, F., 1988. Enodružinska hiša: Od prosto stoječe hiše k nizki zgoščeni zazidavi. Ljubljana, Ambient, 244 pp.

Krevs, M., 1998. Geografski vidiki življenjske ravni prebivalstva v Sloveniji. Doktorska disertacija. Ljubljana, Filozofska fakulteta, 234 pp.

Krevs, M., 2002. Geografski vidiki življenjske ravni prebivalstva Ljubljane. In: Pak, M. (ed.). Geografija Ljubljane. Ljubljana, Filozofska fakulteta, pp. 117-132.

Leitmann, J., 1999. Can city QOL indicators can be objective and relevant? Towards a tool for sustaining urban development. In: Yuan L.L., Yuen B., Low, C. (ed.). Urban quality of life. Critical issues and options. Singapore, Singapore University Press, 250 pp. 
Mandič, S., Cirman, A., 2006. Stanovanje v Sloveniji 2005. Ljubljana, Fakulteta za družbene vede, $218 \mathrm{pp}$.

Mlinar, Z., 1983. Humanizacija mesta. Sociološke razsežnosti urbanizma in samoupravljanja v Novi Gorici. Maribor, Obzorja, 378 pp.

Odlok o prostorskih ureditvenih pogojih za območje urejanja Murgle. 1999. Uradni list Republike Slovenije, 3521-16/98-3.

Pacione, M., 2003. Urban Geography. A Global Perspective. London, Routledge, 703 pp. Population census 1991, 2002 and 2011. Statistical Office of the Republic of Slovenia.

Rebernik, D., 1999. Socialna geografija Ljubljane. Doktorska disertacija. Ljubljana, Univerza v Ljubljani, Filozofska fakulteta, $209 \mathrm{pp}$.

Rebernik, D., 2002. Urbano-geografsko proučevanje blokovskih stanovanjskih sosesk kot urbanističnega planiranja. Dela, 18, 463-475.

Rebernik, D., 2007. Sustainable spatial development and new trends in urban development of Ljubljana. Dela, 27, 17-37. DOI: 10.4312/dela.27.2.17-38.

Rebernik, D., 2013. Social Areas in Ljubljana. Dela 39, 5-26. DOI: 10.4312/dela.39.1.5-26.

Rebernik, D., 2015. Rakova jelša and Siberia - ethnic neighborhoods in transformation. Dela, 44, 63-84. DOI: 10.4312/dela.44.1.63-84.

Špes, M., 1998. Degradacija okolja kot dejavnik diferenciacije urbane pokrajine. Ljubljana, Inštitut za geografijo, 199 pp.

Tiran, J., 2015. Geografsko vrednotenje bivalnega okolja v izbranih slovenskih mestih. Doktorska disertacija. Ljubljana, Univerza v Ljubljani, Filozofska fakulteta, 323 pp.

Toš, N. (ed.), 2014. Vrednote v prehodu VIII. Slovensko javno mnenje 1991-2011. Ljubljana, Univerza v Ljubljani, Fakulteta za družbene vede, 658 pp.

Uršič, M., Kos, D., 2004. Results of the questionnaire survey in Ljubljana. ReUrban Mobil, 40 pp.

\section{KAKOVOST BIVALNEGA OKOLJA V SOSESKI MURGLE - SKANDINAVSKI URBANIZEMV LJUBLJANI}

\section{Povzetek}

Soseska Murgle v Ljubljani je bila zgrajena med koncem šestdesetih in sredino osemdesetih let 20. stoletja in s svojo urbanistično zasnovo z nizko gostoto zazidave prestavlja alternativo prevladujoči stanovanjski gradnji v obliki blokovskih sosesk. Njena avtorja, arhitekta France in Marta Ivanšek, sta želela ustvariti sosesko z zelo kakovostnim bivalnim okoljem, ob tem pa ohraniti relativno visoko gostoto poselitve in racionalno rabo dragocenega mestnega prostora. Zaradi lokacije blizu mestnega središča in na slabo nosilnih barjanskih tleh je bil izbran koncept nizke goste zazidave v obliki pritličnih atrijskih hiš. Zaradi svoje edinstvene urbanistične zasnove je soseska Murgle zavarovana kot primer kakovostne urbanistične kulturne dediščine. Kljub temu pa prihaja do številnih prostorskih posegov, ki niso skladni z določitvami prostorskih ureditvenih pogojev. Na ta način prihaja do razvrednotenja kakovostne urbanistične dediščine. V prispevku želimo ugotoviti, če soseska kljub prostorski preobrazbi ohranja visoko kakovost bivalnega okolja. 
Preučevanje kakovosti bivalnega okolja, ki izhaja iz tradicije behaviorizma, je pomembno raziskovalno vprašanje $\mathrm{v}$ geografiji ter hkrati element urbanističnega načrtovanja, ki lahko veliko prispeva k bolj učinkovitemu urbanemu načrtovanju in razvoju. Bivalno okolje lahko opredelimo kot »prostor, kjer posameznik zadovoljuje svoje osnovne življenjske potrebe in socialne funkcije«. Običajno ločimo tri prostorske ravni bivalnega okolja: stanovanje, soseska in mesto (Tiran, 2015). V naši raziskavi smo se omejili na preučevanje kakovosti bivalnega okolja na ravni stanovanja in soseske. Poglavitni metodološki pristop, ki smo ga uporabili v raziskavi, je anketiranje lokalnega prebivalstva. Anketa je bila zasnovana z namenom, da odgovori na naše temeljno raziskovalno vprašanje: kako lokalno prebivalstvo vrednoti kakovost bivalnega okolja (in še zlasti značilnosti urbanistične zasnove)? Anketiranje je zajelo 380 oziroma več kot $50 \%$ gospodinjstev v soseski Murgle, izvedeno je bilo v mesecu januarju 2016.

Poglavitne značilnosti oziroma posebnosti urbanistične zasnove soseske Murgle so sledeče:

- urbanistična zasnova se v največji možni meri prilagaja naravnemu okolju Ljubljanskega barja;

- ulični sistem z dosledno ločitvijo tranzitnega in avtomobilskega prometa ter pešpoti zagotavlja zelo mirno bivalno okolje;

- celotna soseska ima enotno urbanistično in arhitekturno zasnovo s pritličnimi atrijskimi hišami in ograjenimi vrtovi, kar zagotavlja visoko stopnjo zasebnosti ter hkrati odlično povezanost zasebnih in javnih zelenih površin;

- arhitekturna zasnova stanovanjskih hiš je namenoma enostavna in racionalna, kar zagotavlja odlično rabo stanovanjskih površin.

V soseski Murgle prihaja do številnih nedovoljenih posegov, ki predstavljajo razvrednotenje kakovostne urbanistične zasnove. Najpogostejši primeri so neprimerna obnova stanovanjskih hiš, podaljševanje ograjenih atrijskih vrtov na javne zelene površine in dodajanje prvega nadstropja pritličnim stanovanjskim hišam.

Ob začetku izgradnje je bila soseska Murgle zasnovana kot soseska javnih socialnih stanovanj za ljudi z nižjimi dohodki. Že kmalu pa je zaradi bolj kakovostne gradnje, predvsem pa zaradi kakovostnega bivalnega okolja v bližini središča Ljubljane, soseska postala socialno območje višjega sloja in najbolj »elitno« stanovanjsko območje v Ljubljani. Analiza statističnih podatkov je pokazala, da je soseska tudi v sedanjosti obdržala položaj območja s visokim socio-ekonomskim položajem prebivalstva in prevlado starejših gospodinjstev.

Anketiranje lokalnega prebivalstva je pokazalo, da je velika večina stanovalcev zadovoljna s kakovostjo bivalnega okolja v soseski in stanovanju. Kot najpomembnejše prednosti soseske so anketiranci izpostavili: kakovostno in racionalno arhitekturno zasnovo stanovanjskih hiš, nizke stanovanjske stroške, kakovostno urbanistično zasnovo, visoko estetsko vrednost, visoko stopnjo zasebnosti, obilje zelenih površin ter ločenost avtomobilskega prometa in pešpoti. Kot poglavitne pomanjkljivosti so anketiranci navedli: neprimerno velikost stanovanjske hiše, omejitve pri prenovi, ločitev hiše in garaže, vlažnost bivalnih prostorov in smrad z odlagališča odpadkov (Zbirni center Barje). 
Eden poglavitnih problemom v soseski je tudi pomanjkanje varnosti, saj je bilo že vlomljeno kar v tretjino hiš (lastno anketiranje, 2016). Na osnovi rezultatov anketiranja lahko zaključimo, da stanovalci vrednotijo kakovost bivalnega okolja kot zelo dobro (lastno anketiranje, 2016).

Soseska Murgle je torej 50 let po začetku izgradnje ohranila visoko kakovostno bivalno okolje in predstavlja enega najbolj kakovostnih stanovanjskih območij v slovenskih mestih. Urbanistična zasnova soseske bi lahko postala zgled pri nadaljnji stanovanjski gradnji v slovenskih mestih in obmestjih. 